\title{
Land use history (1840-2005) and physiography as determinants of southern boreal forests
}

\author{
Yan Boucher • Pierre Grondin • Isabelle Auger
}

Received: 7 June 2013/Accepted: 11 December 2013/Published online: 22 December 2013

(C) The Author(s) 2013. This article is published with open access at Springerlink.com

\begin{abstract}
Land use history has altered natural disturbance dynamics, causing widespread modifications of the earth's forests. The aim of this study is to reconstruct a regional, spatially-explicit, fire and logging history for a large southern boreal forest landscape $\left(6,050 \mathrm{~km}^{2}\right)$ of eastern Canada. We then examined the long-term influence of land use history, fires, and physiographical gradients on the area's disturbances regimes, present-day age structure and tree species composition. Spatially-explicit fire (1820-2005) and logging (1900-2005) histories were reconstructed from forestry maps, terrestrial forest inventories and historical records (local newspapers, travel notes, regional historical reviews). Logistic regression was used to model the occurrence of major boreal tree species at the regional scale, in relation to their disturbance history and physiographical variables. The interplay of elevation and fire history was found to explain a large part of the present-day distribution of the four species studied. We conclude that human-induced fires following the colonization activities of the nineteenth and twentieth centuries have increased fire frequency and the dominance of fire-adapted species at lower elevations. At higher elevations, the low historical fire frequency has
\end{abstract}

Y. Boucher $(\varangle) \cdot$ P. Grondin · I. Auger

Direction de la recherche forestière (Forest Research Branch), Quebec Ministry of Natural Resources (QMNR), 2700 rue Einstein, Quebec, QC G1P 3W8, Canada e-mail: yan.boucher@mrn.gouv.qc.ca fostered the dominance of fire-sensitive species. Twentieth-century forestry practices and escaped settlement fires have generated a forest landscape dominated by younger forest habitats than in presettlement times. The expected increase of wildfire activity in North America's eastern boreal forest, in conjunction with continued forest management, could have significant consequences on the resilience of boreal forests.

Keywords Fire - Disturbances legacy · Vegetation pattern $\cdot$ Settlement $\cdot$ Logging . Anthropogenic impact · Historical ecology

\section{Introduction}

Human use of land has caused widespread modifications of the earth's forest ecosystems and is one of the most important components of global change (Foley et al. 2005; Ellis 2011). Human activities associated with settlement, forestry practices, forest conversion to agriculture, and fire suppression have altered natural disturbance regimes in equilibrium with climate and generated vast, human-dominated landscapes (Noble and Dirzo 1997; Gibson et al. 2011). The intensity of human-caused disturbances can rival the most severe natural disturbances. These disturbances can affect extensive areas and modify the forest landscape patterns that result from biotic-environmental relationships (Foster et al. 1998; Turner 2010). Interactions 
among native and non-native biological disturbance agents can generate novel ecological conditions that drive forest communities outside of their historical range of variability (Landres et al. 1999).

Over the last two centuries, Euro-American settlement at the boreal-temperate forest interface in North America has altered the natural disturbance regime (Whitney 1994; Foster et al. 1998; Friedman and Reich 2005). Colonization activities and the resulting escaped settlement fires during the nineteenth and early twentieth centuries have considerably affected the wildfire regime (Foster et al. 1998; Weir and Johnson 1998). Moreover, industrial forestry practices during the twentieth century have increased both the frequency of stand-replacing disturbances and their spatial footprint within forested landscapes (Rhemtulla et al. 2007; Boucher et al. 2009a; Boucher and Grondin 2012). Nowadays, industrial logging has replaced fire as the main stand-replacing disturbance agent affecting the southern portion of North America's boreal forest (Reich et al. 2001). However, the long-term effects of this new disturbance regime on the boreal forest remain largely unknown.

By inducing forest rejuvenation, the new anthropogenic disturbance regime has promoted early successional habitats and the widespread colonization of newly disturbed environments by pioneer species, to the detriment of late-successional species (Higgins and Richardson 1999; Landhäusser et al. 2010). Knowing how contemporary landscape composition has developed under a disturbance regime modified by past land use activities is fundamental to understanding how present-day forests will evolve under anthropogenic stress and global change (Gerhardt and Foster 2002; Robertson et al. 2012). However, documenting land use history and its regional impact on forest structure and composition is challenging, due to the limited availability of consistent long-term and spatially-explicit historical data. The examination of archival documents and the use of historical ecology techniques can help reconstruct past forest landscape dynamics (Foster et al. 1996; Östlund et al. 1997; Williams and Baker 2012).

The aim of this study is to reconstruct a regional, spatially-explicit, fire and logging history in order to examine the long-term influence of land use history, fires, and physiographical gradients (elevation and soil drainage) on the present-day age structure and tree species composition in a large southern boreal forest landscape $\left(6,050 \mathrm{~km}^{2}\right)$ located in eastern Canada. Our study area encompasses a wide range of physiographical conditions and disturbances, representative of the southern boreal forests of North America and Eurasia. We address two general questions: (1) how have escaped settlement fires and logging influenced the stand-replacing disturbance regime and the presentday age structure? and (2) how have fire, logging and physiography influenced the present-day forest landscape composition?

\section{Study area}

The $6,050 \mathrm{~km}^{2}$ study area is located in south-central Québec, eastern Canada, at the southeastern range limit of the boreal forest (Rowe 1972). It extends from $48^{\circ} 21^{\prime} \mathrm{N}$ to $47^{\circ} 37^{\prime} \mathrm{N}$ latitude and from $72^{\circ} 07^{\prime} \mathrm{W}$ to $69^{\circ} 43^{\prime} \mathrm{W}$ longitude (Fig. 1a) in Québec's Laurentian Highlands and the Canadian Shield's Greenville Province (Robitaille and Saucier 1998). The variable topography consists of low hills (100-350 m) along the northern section that is bordered by the Saguenay and the Saint-Lawrence Rivers, and of high hills $(550-1,000 \mathrm{~m})$ in the center and southern sections (Fig. 1b). Mean annual precipitation varies from 800 to $1,600 \mathrm{~mm}$, of which $30-40 \%$ fall as snow. Mean annual temperatures range from -2.5 to $+2.5 \mathrm{C}$. The growing season is short (130-170 days), with $1,600-2,400^{\circ}$ days depending on elevation (Robitaille and Saucier 1998). The study area contains the "South Kenogami" $\left(3,650 \mathrm{~km}^{2}\right)$ and "Lower Saguenay" $\left(2,400 \mathrm{~km}^{2}\right)$ timber harvest limits (Fig. 1b), which were owned by Price Brothers and Company and their successors from the mid nineteenth century to the early 1960s. Company archives contain forest maps and extensive information about past forest management, from the early twentieth century to c. 1960.

Currently, the major forest types are composed of balsam fir (Abies balsamea (L.) Mill.), black spruce (Picea mariana (Mill.) B.S.P.), paper birch (Betula papyrifera (Marsh.) and trembling aspen (Populus tremuloides L.). A few scattered stands of pine (white, red, and jack pine (Pinus strobus L., Pinus resinosa Ait. and Pinus banksiana Lamb.) are found at lower elevations in the northwestern section of the Lower Saguenay limits. Research conducted within the study region (Blais 1965; Cogbill 1985; Delisle-Boulianne et al. 2011; Boucher and Grondin 2012; Couillard et al. 


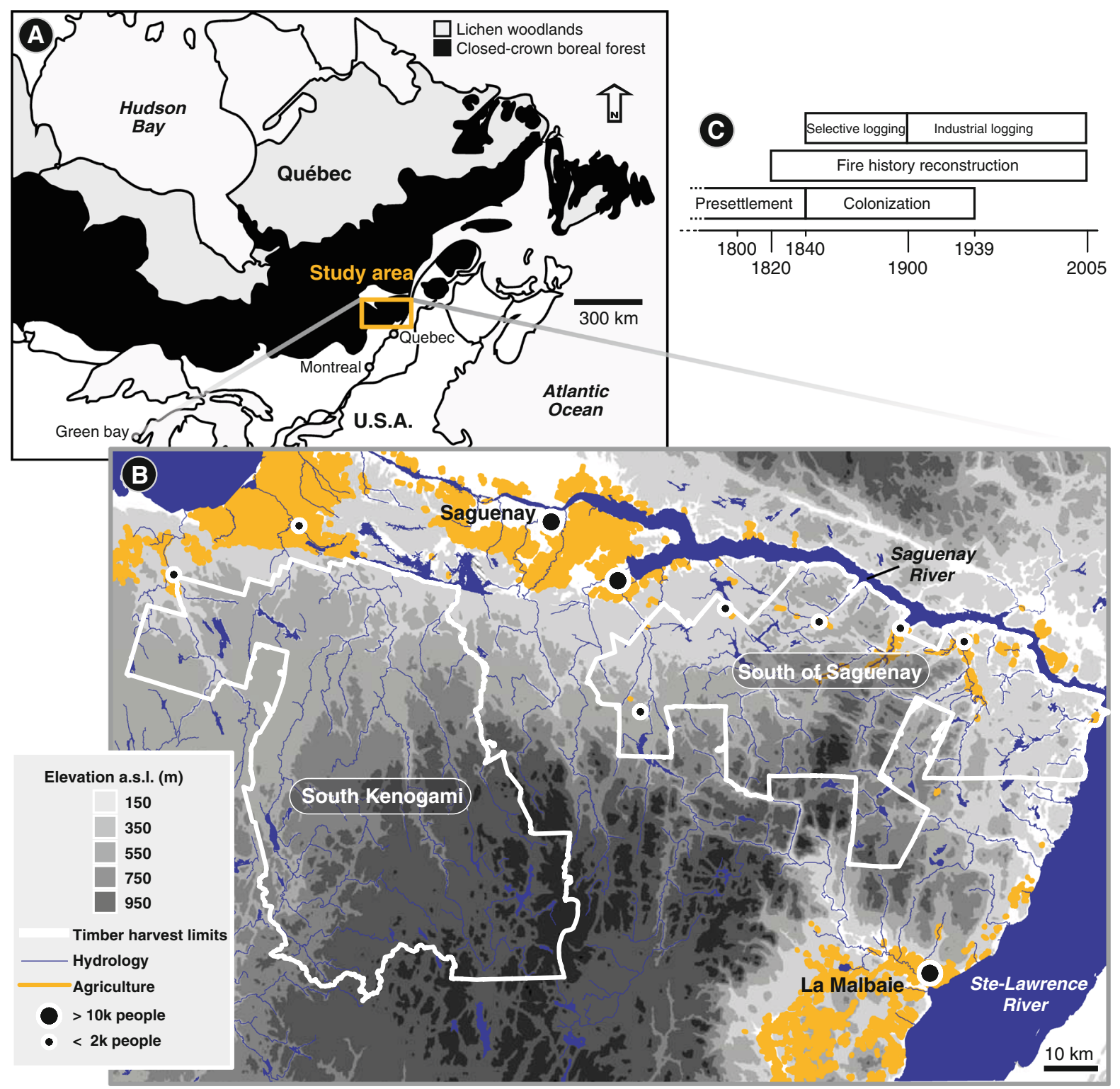

Fig. 1 Location of the study region in the southern boreal forest of Eastern Canada (a); vegetation zones are delineated according to the classifications of Rowe (1972). Timber harvest

2013) indicates that the area's natural disturbance regime was characterized by small-scale disturbances (insect epidemics, canopy-gaps), and fires. Despite the fact that the Innu First Nation occupied the area well before the arrival of the first Europeans, nothing in the ethnographic literature indicates their use of fire, unlike what has been documented in other parts of northeastern America (Russel 1983). Although Europeans began colonizing the vicinity of Québec city limits, elevation gradient, present-day agricultural area, and locations of cities, villages and hamlets (b); Time scale of major historical events in the study area (c)

(see Fig. 1a) at the end of the seventeenth century, settlement in the study area only started around the mid-nineteenth century, when the Hudson's Bay Company was forced to open its territory to logging to meet England's needs (Girard and Perron 1989; Vallières et al. 2008; Fig. 1c). Settlement brought on selective logging for saw-timber along main watercourses, mainly large-diameter pines and white spruce (Picea glauca (Moench) Voss). Extensive industrial 
logging only began at the turn of twentieth century, with an increasing demand for pulp and paper. During this period, even-aged management was the main silvicultural system, targeting conifer trees (Girard and Perron 1989; Boucher and Grondin 2012).

\section{Methods}

\section{Data collection}

\section{Fire history reconstruction-fire frequency map}

A fire history map delineating events $>200$ ha was drawn from multiple archival sources and validated by field sampling. First, the most recent (1950-2005) fires were directly mapped using the Quebec Ministry of Natural Resources (QMNR) fire database. Second, for fire events dated from 1900 to 1950, we used a set of old forestry maps created by Price Brothers and Company in 1925, 1937, and 1955. A complete description of archival sources and methodology is available in Delisle-Boulianne et al. (2011). Information concerning cover types, age classes, cutovers, and fires recorded on each historical map was digitized in a vector format and georeferenced using ArcGis 9.3 (ESRI 2008). Fire years for events that occurred between 1900 and 1950 were already identified on these historical forestry maps. Third, for fires prior to 1900, we combined the 1925 maps with an extensive field survey to delineate and date fire boundaries. On the 1925 maps, because post-fire stands are dominated or co-dominated by early-successional deciduous species during the first $80-100$ years, we selected immature (20-60 years) and young merchantable (60-80 years) hardwood and mixedwood stands to determine the age of fire events. For areas that had not been disturbed since 1925, field validation was performed in QMNR age survey plots (0.04 ha) used in the four decennial provincial forest surveys (1964-2005) and distributed over the study area. In each of these plots, the age of dominant trees was derived from dating cores (see Bouchard et al. 2008 for details). During the summers of 2010 and 2011, for suspected post-fire stands where QMNR age survey plots were unavailable, we conducted our own age survey plots using a similar methodology. 10 to 15 samples of post-fire species (trembling aspen, black spruce or paper birch) were tallied at each stand for age determination. When a relatively even-aged (maximum variation of 20 years) structure was observed, we identified the fire date of each burned area using the age of the oldest post-fire tree. Stands with an uneven-aged structure were considered not to have burned (see Lefort et al. 2003 for similar methodology).

To confirm whether fires ignited after 1950 originated from natural or human causes, we used Quebec's government fire database, which contains a record of fire origin. For earlier fire events, we used forest management working plans (Price Brothers and Company, Ltd. 1940), local newspapers and historical records (Bouchard and Martin 1988; Girard and Perron 1989; Proulx 2007) to identify human-caused fires. Otherwise, fires were considered of "natural or unknown" origin. Finally, the mapping of successive fire events served to produce a fire frequency map (Table 1) for fires ( $>200$ ha) that occurred during the 1900-2005 period. Unfortunately, fires prior to 1900 were underestimated because only the largest ones were detected ( $n=10$; from 9,600 to 36,042 ha; mean: 21,512 ha).

\section{Historical reconstruction of twentieth century industrial logging}

The history of twentieth-century industrial logging was reconstructed using maps elaborated by Price Brothers and Company in 1925, 1937, and 1955, and those of the last four decennial provincial forest survey maps $(1964,1983,1991$, and 2005). For each map, the

Table 1 Description and relative abundance of fire frequency classes in the study area

\begin{tabular}{|c|c|c|}
\hline $\begin{array}{l}\text { Fire } \\
\text { frequency } \\
\text { class }\end{array}$ & Description & $\begin{array}{l}\text { Landscape } \\
\text { area }(\%)\end{array}$ \\
\hline F0 & No fire detected & 45.1 \\
\hline F1a & $\begin{array}{l}\text { Only one fire in 19th century } \\
(1820-1899)\end{array}$ & 21.6 \\
\hline $\mathrm{F} 1 \mathrm{~b}$ & $\begin{array}{l}\text { Only one fire in 20th century } \\
(1900-2005)\end{array}$ & 29.1 \\
\hline $\mathrm{F} 2 \mathrm{a}$ & $\begin{array}{l}\text { Two fires or more over the 19th } \\
\text { and 20th centuries }(1820-2005)\end{array}$ & 3.0 \\
\hline $\mathrm{F} 2 \mathrm{~b}$ & $\begin{array}{l}\text { Two fires or more over the 20th } \\
\text { century }(1900-2005)\end{array}$ & 1.2 \\
\hline
\end{tabular}


areas affected by clear-cut logging ( $\geq 75 \%$ of basal area removal) were identified (see Boucher and Grondin 2012 for details). We calculated the spatial logging patterns for three broad time intervals: prior to 1925 (1900-1925), 1925-1965, and 1965-2005. The early selective logging operations for saw-timber started around 1840 and were confined to large pine and spruce stems at low-elevation sites near lakes and rivers (Girard and Perron 1989; Boucher et al. 2009b). We did not consider these early operations in our analysis due to their relatively low intensity, their negligible impact on forest landscape (age structure and composition) and the lack of spatially-explicit documents showing precisely where logging took place. To determine the relative influence of each disturbance type, we estimated logging and fire rotation lengths using the technique proposed Johnson and Gutsell (1994), which is based on the reciprocal of the annually disturbed area. The disturbance rotation $(D R)$ was estimated with the following formula: $D R=$ $1 / \sum T a / P A / 100$ where $T a$ is the percentage (\%) of the area affected by the disturbance on each map, and $P A$ is the period of analysis.

\section{Present-day forest cover and physiographical variables}

The present-day (2005) forest landscape composition and age structure were characterized using Québec's last decennial provincial forest survey map, elaborated using aerial photographs (infrared-false colours; scale $1: 15,000)$ taken from 2002 to 2005. Forest cover composition was reclassified into four broad types: 1-black spruce, 2-balsam fir, 3-paper birch, and 4 - trembling aspen dominated stands. For a stand to be classified into one of these four types, the dominant species had to occupy more than $50 \%$ of the stand basal area (see QMNR 2008 for details). Composition of young stands ( $\leq 20$ years) was not included in the analysis because their composition is difficult to estimate from aerial photographs. Uncommon forest cover types, unproductive land (including water bodies) and naturally deforested zones were also excluded from the analysis. We also described the present-day age class distribution of the landscape using four broad classes (Table 2). Regional environmental data were compiled to assess the importance of physiographical gradients on forest landscape composition and disturbance patterns. Elevation above sea level (a.s.l.) was calculated using a digital elevation model built from hypsometric maps provided by the QMNR (2000). Soil drainage data were obtained from provincial maps (1:50,000 scale) derived from aerial photographs and field sampling (QMNR 2008). A cross-tabulation procedure of $\mathrm{R}$ software version 2.15.2 ( $\mathrm{R}$ Development Core Team, Vienna, Austria) contained in the Matrix 1.10 package (Bates and Maechler 2007) was used to study the relationship between elevation (elevation band used as the common sample unit), landscape composition, fire frequency, and logging.

\section{Statistical analysis-determinants of forest cover composition}

Sampling design We used variogram analysis (Isaaks and Srivastava 1989) to assess spatial autocorrelations in forest cover composition, using the SAS software with the VARIOGRAM procedure (SAS Institute 2011). Due to spatial autocorrelation up to $1 \mathrm{~km}$, we created a spatial database by systematically sampling points on a $1,000 \times 1,000 \mathrm{~m}$ grid. The resulting 3,529 points were considered independent. We then assigned forest cover composition according to Québec's last decennial provincial forest survey map, disturbance history (fire frequency class, presence or absence of logging), and physiographical (elevation, drainage) variables to each sampling point (Table 3 ).

Table 2 Correspondence between age classes used in this study and classifications on the 2005 map

\begin{tabular}{|c|c|}
\hline $\begin{array}{l}\text { Age class in the present } \\
\text { study (years) }\end{array}$ & 2005 map \\
\hline 0-20 (Young) & $\begin{array}{l}10 \text { years, Clear-cut, plantation, } \\
\text { recently naturally-disturbed stand }\end{array}$ \\
\hline 20-60 (Immature) & $\begin{array}{c}30,30-50 *, 30-70 *, 50,50-90 \\
\text { years*, young uneven-aged }\end{array}$ \\
\hline $\begin{array}{l}\text { 60-80 (Young } \\
\text { merchantable) }\end{array}$ & $70,70-30^{*}, 70-50$ years* \\
\hline $\begin{array}{l}>80 \text { (Mature and old } \\
\text { forests) }\end{array}$ & $\begin{array}{l}90,90-50 * 100 \text { years and over, old } \\
\text { uneven aged }\end{array}$ \\
\hline
\end{tabular}

The story which occupies the most important part of the stand basal area (mentioned first), is used to define the age class

* Two-storied stand 
Table 3 List of variables included in the disturbance and physiography families of variables

\begin{tabular}{lll}
\hline $\begin{array}{l}\text { Family of } \\
\text { variable }\end{array}$ & Variable & Type/description \\
\hline Disturbances & Fire & $\begin{array}{c}\text { Categorical (5)/fire frequency } \\
\text { index classes (see table 1) } \\
\text { Categorical (2)/presence or } \\
\text { absence of logging } \\
\text { Physiography }\end{array}$ \\
Drainage & $\begin{array}{c}\text { Categorical (3)/slow, moderate, } \\
\text { excessive } \\
\text { Continuous/elevation above sea } \\
\text { level (a.s.1.) }\end{array}$ \\
\hline
\end{tabular}

Logistic regression We used logistic regression to model the probability of presence or absence of the four major forest cover composition types as a function of disturbance history and physiographical variables (Clark and Hosking 1986). Regressions were calculated independently for each of the four cover types using the PROC LOGISTIC function in the SAS software package (SAS institute 2003). The Akaike information criterion was also calculated. In our study, 14 alternate models were compared for each forest cover composition type (Table 4). A first series of models was built including fire frequency class, presence or absence of logging, and soil drainage class (Table 4). Another set of models was created by incorporating elevation into the first group of models. We used model averaging when the AICc weight of the top-ranking model was $<0.95$. Average parameter estimates and associated unconditional standard errors were calculated from the subset of the top-ranking models for which the sum of AICc weights reached 0.95. Goodness of fit of the best model for each cover type was quantified from the area under the receiver operating characteristic (ROC) curve, which measures the model's ability to discriminate between presence or absence of a species. Diagnostic plots using standardized deviance residuals were visually inspected to verify that all observations were well explained by the model (Hosmer et al. 2013).

\section{Results}

Fire and logging history reconstruction

Our fire history reconstruction allowed us to detect events that occurred from 1820 to 2005 . During this
Table 4 Candidate models used to relate forest cover composition to disturbance history and physiography. Independent variables used in the models are defined in Table 3

\begin{tabular}{llll}
\hline $\begin{array}{l}\text { No. } \\
\text { Wodel }\end{array}$ & No. & $\begin{array}{l}\text { Model } \\
\text { With elevation }\end{array}$ \\
\hline 1 & Fire & 8 & Elevation fire \\
2 & Logging & 9 & Elevation logging \\
3 & Fire logging & 10 & Elevation fire logging \\
4 & Drainage & 11 & Elevation drainage \\
5 & Fire drainage & 12 & Elevation fire drainage \\
6 & Logging drainage & 13 & Elevation logging drainage \\
7 & Fire logging & 14 & Elevation fire logging \\
& drainage & & drainage \\
\hline
\end{tabular}

period, fires ( $>200$ ha) affected $59.1 \%$ of the study area, with $4.2 \%$ of the area being affected twice (Figs. 2, 3; Table 1). This is equivalent to an overall fire rotation estimate of 315 years. The fire rotation estimated for the settlement period (1840-1939: fire rotation of 226 years) was five times shorter than the post-settlement period (1940-2005: 1117 years). Our historical records also reveal that at least $53.7 \%$ of the total burned area originated from escaped settlement fires (land clearings), that occurred mainly during the 1875, 1905, and 1915 decades (Figs. 2, 3). With regard to the fire frequency index (Table 1), 21.6, and $29.1 \%$ of the landscape was classified as F1a and F1b, respectively. Sites in the F1b class were generally associated with low-elevation areas $(<600 \mathrm{~m})$, whereas F1a-class sites were more frequent on higher elevation sites (>600 m; Fig. 4). Areas burned twice were mostly located in the low-elevation bands and represented only $3.0 \%$ (F2a) and $1.2 \%$ (F2b) of the landscape area. The fire rotation was 267 years on low-elevations sites, and 501 years on high-elevation sites.

Industrial logging affected $81.7 \%$ of the study area from 1900 to 2005 (Fig. 5), which corresponds to a rotation of 129 years. The elevational distribution of cutover areas changed considerably from 1900 to 2005 (Fig. 6). During the 1900-1925 period (Fig. 6a), most logged areas were in the lowlands, whereas they tended to be at higher elevations during the 1925-1965 period (Fig. 6b). The distribution of the most recent period (1966-2005; Fig. 6c) resembled that of prior to 1925 , but covered larger parts of the landscape area at all elevation bands. The present-day age structure 


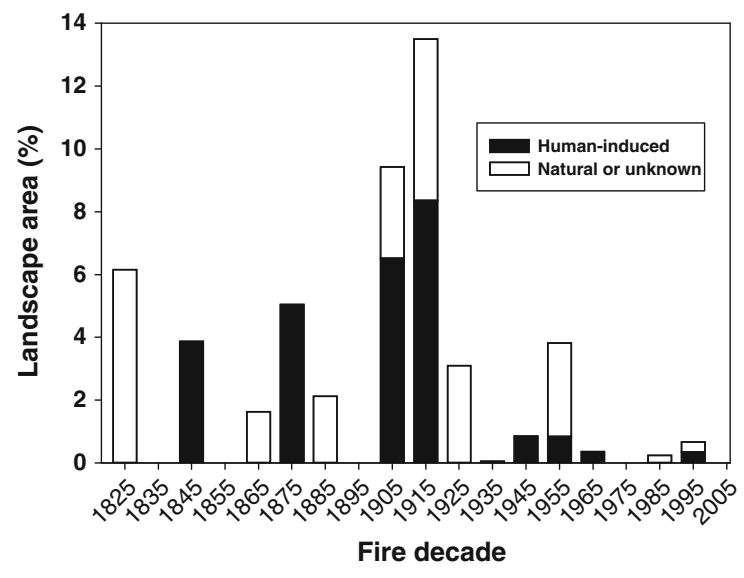

Fig. 2 Proportion of the study area burned by origin of fires (>200 ha) detected from 1820 to 2005

reflects the high prevalence of stand-replacing disturbances over the last century, with a dominance $(83.4 \%)$ of immature stands $(<60$ years). Young merchantable (60-80 years) and mature and old forest ( $>80$ years) age classes cover only 8.2 and $8.4 \%$ of the study area, respectively.

Forest cover composition versus disturbance history and physiography

The interaction of disturbances and physiography greatly influences forest cover composition in the study area. The top-ranking models predicting the occurrence of cover types for each species always include elevation, fire, and drainage as predictor variables (Table 5). For black spruce, paper birch, and trembling aspen, the best model includes these three predictors (model 12, $\mathrm{w}=0.70,0.43$ and 0.69 for the three species, respectively Table 5). The $95 \%$ confidence interval of the average coefficients always excludes zero, overall or at least for one of the levels in the case of categorical variables (Table 6). This indicates that all three predictors are significantly correlated with the presence of each cover type.

Balsam fir is the only species for which the best model includes logging as a fourth predictor (model $14 ; \mathrm{w}=0.97$, Table 5 ). The $95 \%$ confidence interval of the average coefficients always excludes zero (Table 6), indicating significant correlations with the presence of the balsam fir cover type. The high $\mathrm{AIC}_{\mathrm{c}}$ weight $(\mathrm{w}>0.80)$ of this model indicates that the other models are not well supported.
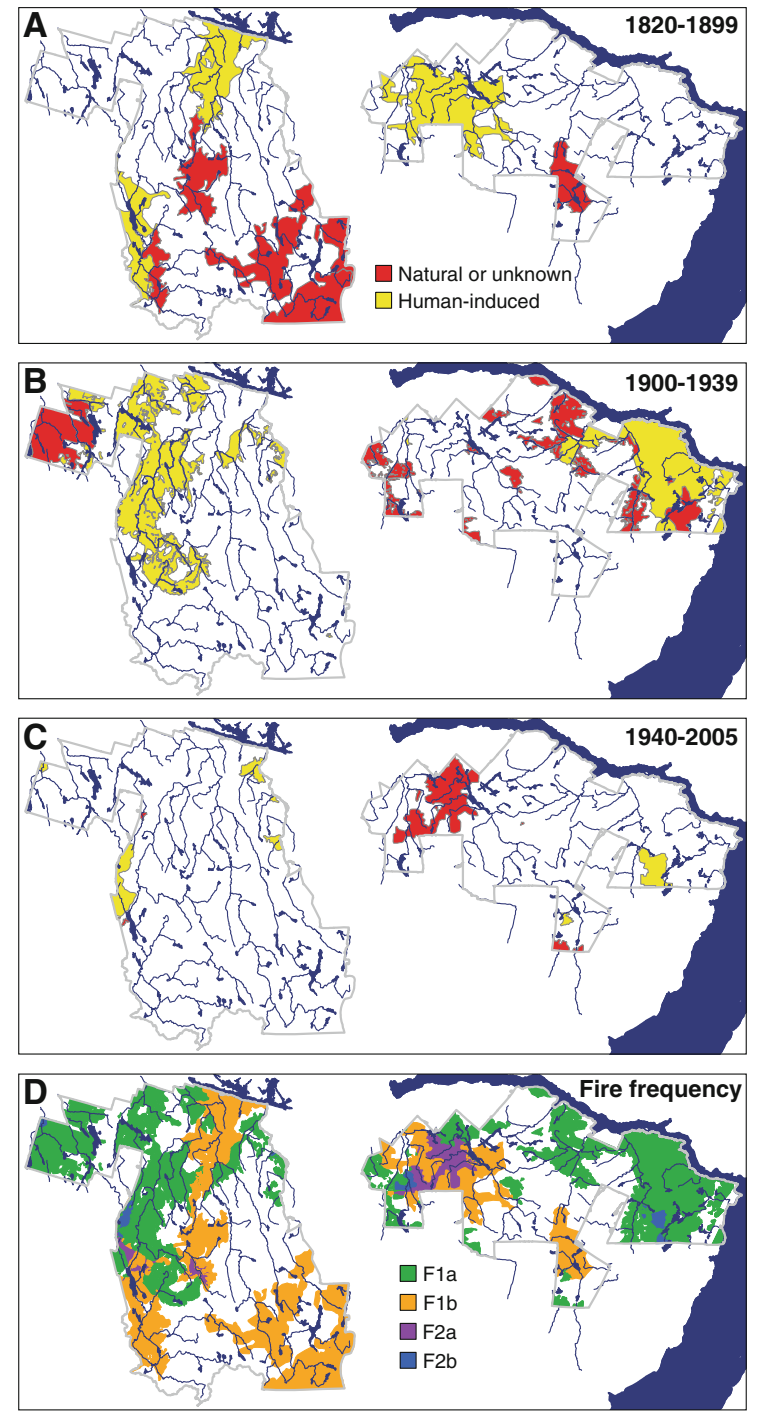

Fig. 3 Maps of fires over the study area for 1820-1899 (a), 1900-1939 (b) 1940-2005 (c), and of fire frequency classes (d)

The ability of the best models for balsam fir, black spruce and trembling aspen to discriminate between absence and presence of cover types is acceptable, as indicated by the area under the ROC curve valued at $0.76,0.70$ and 0.74 , respectively, for the three species (Hosmer et al. 2013). For paper birch, however, this value is 0.63 . Visual examination of standardized deviance residuals revealed no problems with individual fit of observations.

We conducted model averaging for black spruce, paper birch and trembling aspen, and used the best model for balsam fir to draw inferences about the variables correlated to cover composition (Fig. 7). 


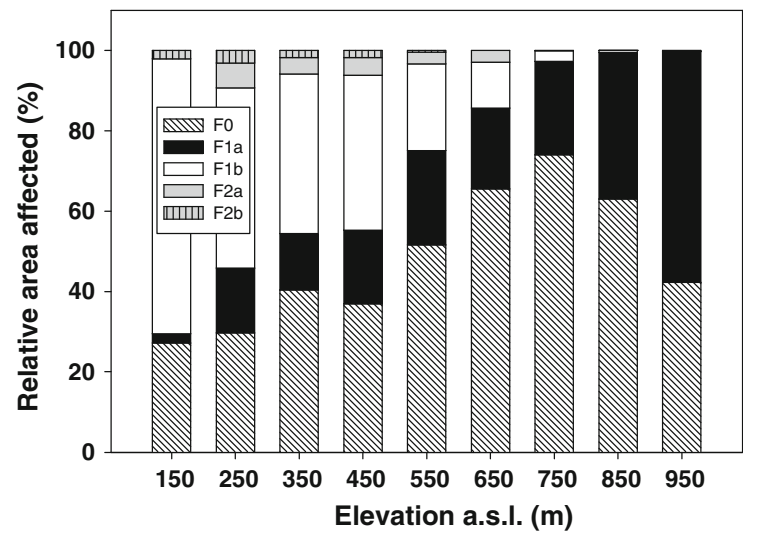

Fig. 4 Relative affected area for each elevation band according to the fire frequency class over the study area
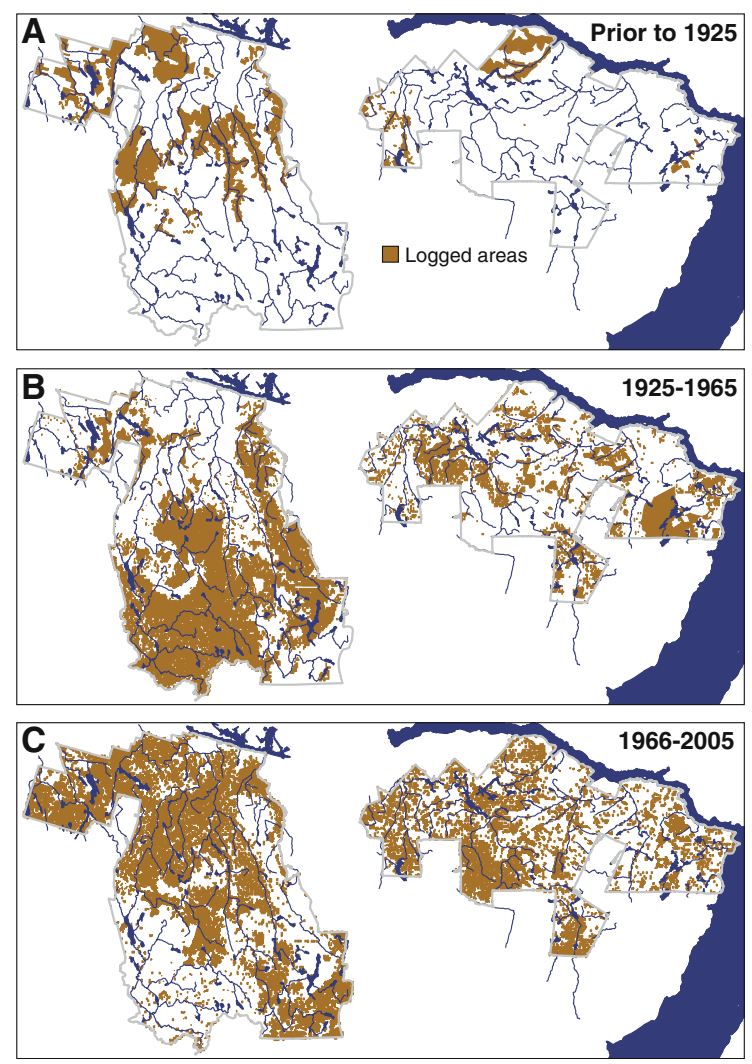

Fig. 5 Logged areas, as reconstructed from historical maps, for periods prior to 1925 (a), 1925-1965 (b) and 1966-2005 (c)

The logistic regression model and the cross-tabulation analysis show that cover occurrence increases with elevation for conifer species, but decreases for deciduous species (Table 6; Figs. 7a, 8). Trembling aspen abundance is highest in the lowlands and decreases as

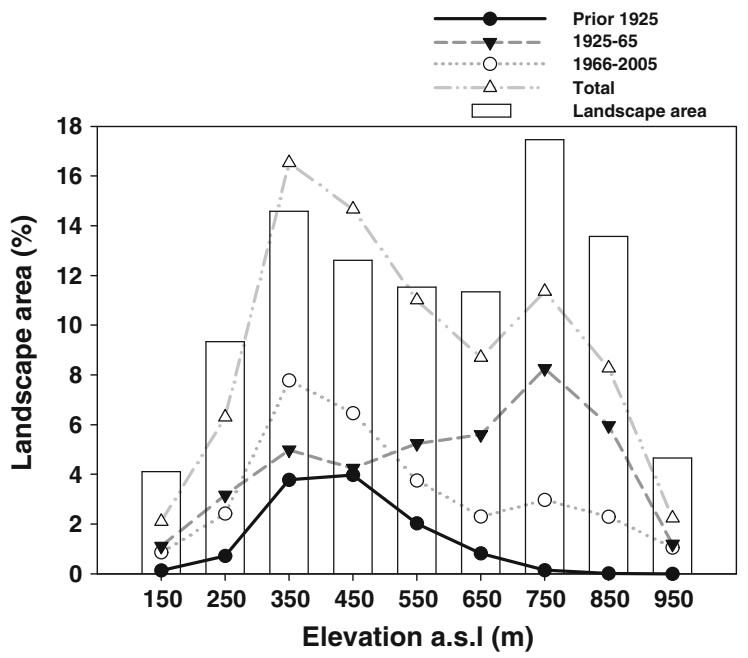

Fig. 6 Variation in the proportion of study area logged according to elevation bands, overall and for periods prior to 1925, 1925-1965 and 1966-2005

a function of elevation, until the species disappears above $600 \mathrm{~m}$. Balsam fir abundance is lowest in the lowlands $(<600 \mathrm{~m})$ and greatest at higher elevations (>600 m). Only trembling aspen abundance shows a significant positive correlation with all classes of fire frequency (Table 6; Fig. 7b). In contrast, balsam fir and paper birch abundance is negatively correlated with fire. Logging appears to have the least influence, given that the $95 \%$ confidence interval of the average regression coefficient for this predictor includes 0 for all species except balsam fir; even for this species, logging is the least influential predictor (Table 6; Fig. 7c). Compared to moderate drainage conditions, extreme drainage negatively affects the occurrence of balsam fir, paper birch, and trembling aspen (Table 6; Fig. 7d). In contrast, it has a strong positive effect on black spruce.

\section{Discussion}

The long-term reconstruction of human land use and fire events in our study region poses several methodological challenges related to the limited availability of archives and the difficulties in detecting logging and fires boundaries, especially considering the large temporal and spatial scales of analysis. Nonetheless, our use of historical ecology techniques reveals that human influence since the settlement of the area, combined with physiography, have been the driving 
Table 5 Top-ranking models retained for model averaging among the 14 candidate models predicting the presence of black spruce, paper birch, trembling aspen and balsam fir cover types, as assessed by Akaike's information criterion corrected for small sample sizes (AICc). Number of estimated parameters including the intercept (K), AICc, the difference in AICc $(\triangle \mathrm{AICc})$, and AICc weight $(\mathrm{w})$ are provided. Models in bold were retained for model averaging. The area under the ROC curve is provided for the best model

\begin{tabular}{|c|c|c|c|c|c|c|c|}
\hline Species & No. & Model & $\mathrm{K}$ & $\mathrm{AICc}$ & $\triangle \mathrm{AICc}$ & $\mathrm{W}$ & ROC \\
\hline \multirow[t]{2}{*}{ Black spruce } & 12 & Elevation + fire + drainage & 8 & 4093.2 & $\mathbf{0 . 0}$ & 0.70 & 0.70 \\
\hline & 14 & Elevation + fire + logging + drainage & 9 & 4094.9 & 1.7 & $\mathbf{0 . 3 0}$ & \\
\hline \multirow[t]{4}{*}{ Paper birch } & 12 & Elevation+fire +drainage & 8 & 3785.3 & $\mathbf{0 . 0}$ & 0.43 & 0.63 \\
\hline & 14 & Elevation + fire +logging + drainage & 9 & 3786.0 & 0.7 & 0.30 & \\
\hline & 11 & Elevation+drainage & 4 & 3787.6 & 2.3 & 0.14 & \\
\hline & 13 & Elevation + logging + drainage & 5 & 3787.7 & 2.3 & 0.13 & \\
\hline \multirow[t]{2}{*}{ Trembling aspen } & 12 & Elevation + fire + drainage & 8 & 1880.1 & $\mathbf{0 . 0}$ & 0.69 & 0.74 \\
\hline & 14 & Elevation + fire + logging + drainage & 9 & 1881.7 & 1.6 & 0.31 & \\
\hline \multirow[t]{2}{*}{ Balsam fir } & 14 & Elevation +fire +logging + drainage & 9 & 4010.4 & $\mathbf{0 . 0}$ & 0.97 & 0.76 \\
\hline & 12 & Elevation + fire + drainage & 8 & 4017.4 & 7.1 & 0.03 & \\
\hline
\end{tabular}

factors that shaped the present-day age structure and composition of the southern boreal forest of eastern Canada.

The influence of land use on disturbance regime

The Euro-American colonization that began in the early nineteenth century modified the nature and frequency of stand-replacing disturbances in the study area. During the colonization period (1840-1939), the many slash fires escaping to neighboring forests greatly increased the influence of fire in the lowelevation zone. After this colonization period, fire rotation increased fivefold, from 226 to 1117 years. Since the 1930s, the reduction in total area of humaninduced fires accompanying the end of colonization activities seems to have drastically reduced the area of burned forests, though an unfavorable climate for fire (Flannigan et al. 2005) and fire suppression (Pechony and Shindell 2010) may also have played a role, Colonization activities have also been shown to influence fire regimes elsewhere in North America's southern boreal forest (Weir and Johnson 1998; Lefort et al. 2003; Dupuis et al. 2011) and in Eurasia (Lindbladh and Bradshaw 1998; Achard et al. 2006).

The introduction of industrial logging at the start of the twentieth century considerably increased the frequency and spatial footprint of stand-replacing disturbances. Over time, logging has greatly affected most of the regional forest and modified its age structure. The history and spatial distribution of harvested patches reflect the landcape's physical constraints. Areas logged at the start of the twentieth century were selected according to both their elevation and their position in the watershed. Low-elevation sites, often associated with gentle slopes, allowed for the hauling of logs by horses, while sites close to watercourses permitted the transport of wood to downstream mills using waterways. In the second half of the twentieth century, the arrival of mechanized logging and the creation of a denser road network reduced physical constraints (Törnlund and Östlund 2002) and allowed timber to be harvested across a much larger elevational gradient. At the same time, lands in low-elevations areas which had burned during the early twentieth century became sufficiently mature to be logged. A similar harvesting pattern according to landscape's physical constraints has been observed elsewhere in the boreal forests of North America (Judd 1989; Boucher et al. 2009a; Johnson and Miyanishi 2012) and northern Eurasia (Nilsson et al. 2005). During the twentieth century, logging was by far the most frequent stand-replacing disturbance. In combination with human-induced fire, it created a landscape age structure dominated by forests younger than in presettlement times. This phenomenon has also been observed elsewhere in North America (Frelich 1995; Cyr et al. 2009; Boucher and Grondin 2012) and Eurasia (Östlund et al. 1997; Achard et al. 2006; Hellberg et al. 2009). 


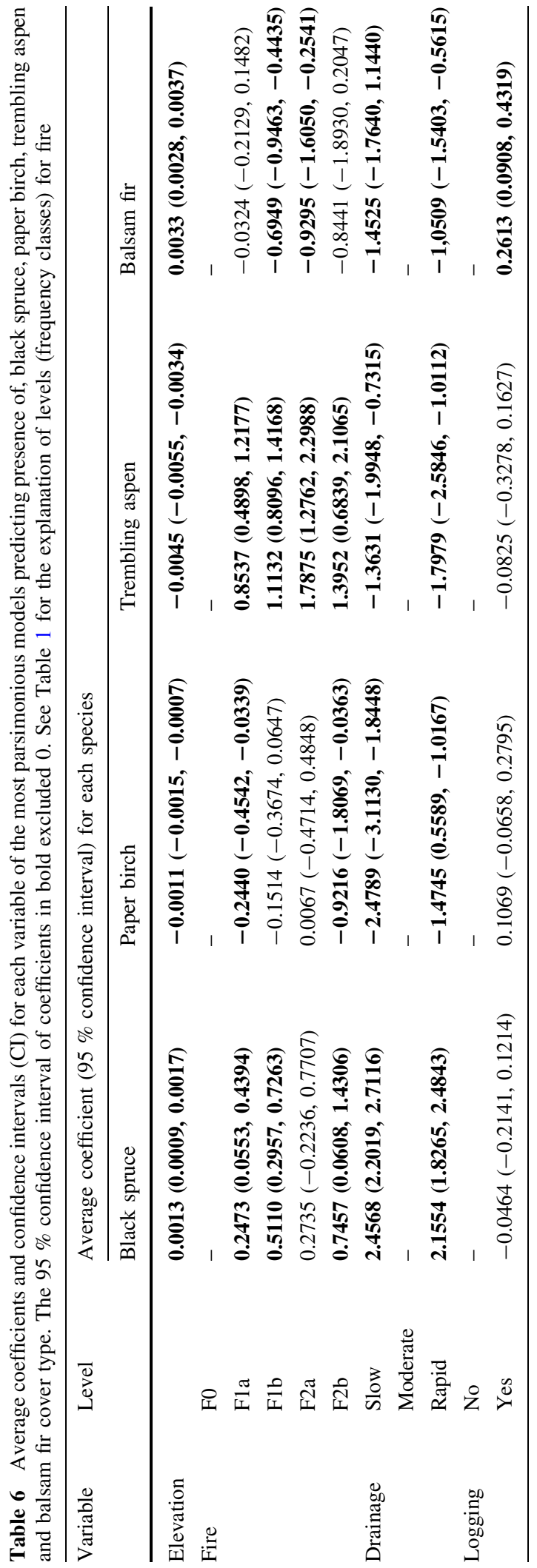

The influence of physiography and disturbance on landscape composition

Elevation influences the spatial distribution of species in the landscape through its effect on climate, soils, and the consequent disturbance regime (Overpeck et al. 1990; Martin et al. 2007). The observed elevational differences in fire regime and landscape composition enable us to divide the study area into two broad zones of low ( $<600 \mathrm{~m} ; 52 \%$ of the area) and high ( $>600 \mathrm{~m}$; $48 \%$ of the area) elevation.

In the low-elevation zone, fires were frequent due to the combined effects of climate and colonization activities. To occur, fires require a favorable climate, flammable vegetation and an ignition source (Parisien et al. 2010); all three conditions are found within the low-elevation zone. The drier conditions of the lowlands reduce the moisture levels of combustible materials; in turn, this increases the probability of fire (Flatley et al. 2011). The unintentional escape of slash fires, which occur almost exclusively at low elevations, also increases the number of ignition sources. The current composition of the low-elevation zone is dominated by black spruce and trembling aspen, which are well adapted to fire. They can rapidly regenerate from seed to re-occupy burned areas, even after successive fires (Zasada 1992). Trembling aspen's capacity to create root suckers at an early age $(<20$ years $)$ gives it an additional advantage in environments with short fire intervals (Weir and Johnson 1998). In contrast, balsam fir, a shade tolerant late-successional species not adapted to fire (Rowe and Scotter 1973), is relatively uncommon in fireprone ecosystems.

In the high-elevation zone, fire frequency has been low in the last few centuries, as indicated by the dominance of balsam fir combined with the absence of fire-dependent species such as trembling aspen and jack pine (Ali et al. 2008; Cyr et al. 2012). The cold and rainy climate in the higher elevation forests of eastern North America does not favor fires (Reiners and Lang 1979; Flatley et al. 2011). The fact that the high-elevation zone was not intensively affected by human activities until the beginning of the twentieth century (Boucher and Grondin 2012) reduces the past influence of anthropogenic fires. Trembling aspen is also absent, but since it is very frost tolerant and can establish itself under climatic conditions that are much more rigorous than those of the study area (Sakai and 
Fig. 7 Predicted probability of presence of balsam fir, black spruce, paper birch and trembling aspen, as predicted by the average model (see Tables 5, 6) for elevation (a); fire frequency class (b); presence of logging (c) and drainage class $(\mathbf{d})$

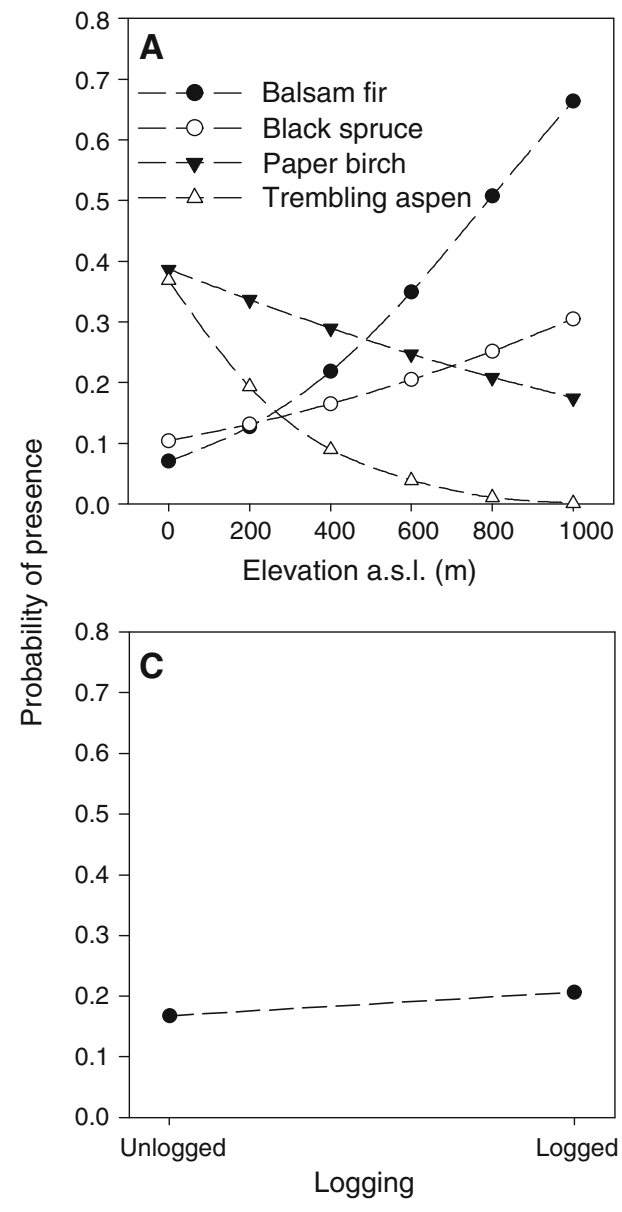

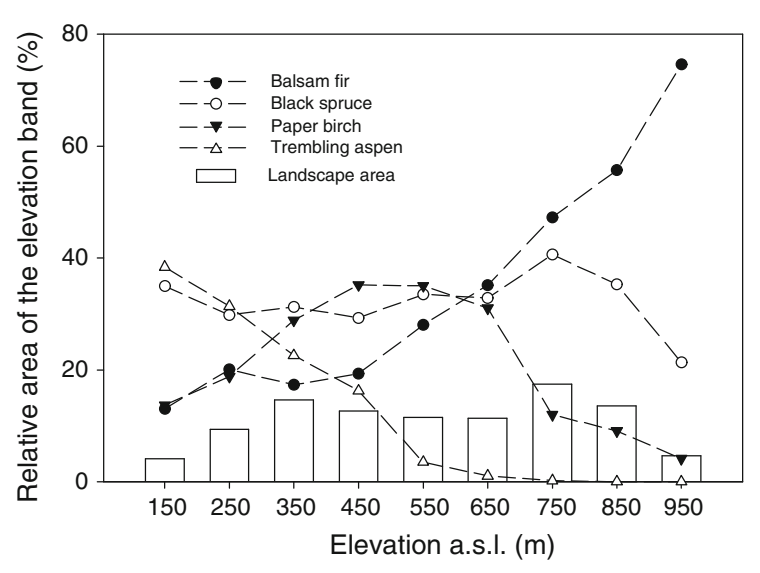

Fig. 8 Present-day (2005) forest composition according to the elevation gradient

Weiser 1973), this cannot be attributed to low temperatures at high elevations. Recent research conducted in the study area (Couillard et al. 2013) supports our results and shows the low influence of fire over the last 4,500 years. While fires became less frequent at elevations higher than $600 \mathrm{~m}$, black spruce abundance did not vary much between elevation zones. The species is ubiquitous and can persist in environments with either short ( $<250$ years) or long (>500 years) fire intervals (Bouchard et al. 2008; Cyr et al. 2012). Over long periods, black spruce can maintain itself due to its longevity ( $>250$ years), its shade tolerance, and its capacity for layering (Doucet 1988; Kneeshaw and Gauthier 2003). Contrary to other species, it is also very tolerant to different drainage conditions and can occupy soils ranging from poorly drained organic deposits to excessively drained rocky outcrops (Viereck and Johnston 1990).

While logging has undoubtedly influenced the age structure of the study area, its influence on landscape composition is not demonstrated as clearly as that of fire. Balsam fir is the only species that was 
significantly affected by logging. The effect was slight and most likely caused by the elimination of the canopy layer and the resulting release of balsam fir seedlings that are typically well-established in the understory of mature coniferous stands (Hatcher 1960). We expected a positive response of trembling aspen to logging, as in other studies conducted in Canada's eastern boreal forests (Carleton and MacLellan 1994; Laquerre et al. 2009; Bouchard and Pothier 2011), but no significant relationship was found. Fire appears to be the decisive disturbance explaining the presence of trembling aspen in our study area.

\section{Conclusion}

This retrospective study clearly shows that anthropogenic activities have greatly modified the natural disturbance regime of the study area since the early nineteenth century. The strong elevational gradient was key in determining forest structure and composition, by its influence on the disturbance regime and historical land use. Settlement activities and industrial logging have radically rejuvenated the age structure of the present-day forest landscapes, by modifying the nature and by increasing the frequency of standreplacing disturbances. The many escaped settlement fires have promoted the proliferation of fire-adapted species such as aspen and black spruce in the lowelevation zone of the study area. Our results show that twentieth-century forestry practices have replaced fire as the principal dynamic agent in the region's forests. Considering that logging will continue and that the fire frequency is predicted to increase in North America over the next century (Bergeron et al. 2010), further research is necessary to identify the long-term consequences of these modified disturbance regimes on the resilience of the boreal forest. To reach the goals of sustainable management, forestry practices should try to maintain the boreal forest inside its natural range of variability, while considering the influence of climate.

Acknowledgments This study was financed by the QMNR (Project No. 112310086) and Coop Quatre-Temps. We also thank J. Noël, M. Jacques, V. Poirier and G. Lanthier for help with geodatabase and fieldwork and P. Jasinsky, D. Tousignant and D. Christiansen-Stowe for English revision. The staff from Archives Nationales du Québec gave help concerning the Price Brothers \& Company's archives. We would also like to thank three anonymous reviewers with their constructive comments, which improved this manuscript.
Open Access This article is distributed under the terms of the Creative Commons Attribution License which permits any use, distribution, and reproduction in any medium, provided the original author(s) and the source are credited.

\section{References}

Achard F, Mollicone D, Stibig H-J, Aksenov D, Laestadius L, Li Z, Popatov P, Yaroshenko A (2006) Areas of rapid forestcover change in boreal Eurasia. For Ecol Manag 237:322-334

Ali AA, Asselin H, Larouche A, Bergeron Y, Carcaillet C, Richard PJH (2008) Changes in fire regime explain the Holocene rise and fall of Abies balsamea in the coniferous forests of western Quebec, Canada. Holocene 18:693-703

Bates D, Maechler M (2007) Matrix: a matrix package for R. R package version $0.99875-2$

Bergeron Y, Cyr D, Girardin MP, Carcaillet C (2010) Will climate change drive 21 st century burn rates in Canadian boreal forest outside of its natural variability: collating global climate model experiments with sedimentary charcoal data. Int J Wild Fire 19:1127-1139

Blais JR (1965) Spruce budworm outbreaks in the past three centuries in the Laurentide park, Québec. For Sci 11:130-138

Bouchard R, Martin J (1988) Ville de La Baie: une fenêtre sur le monde depuis 150 ans. Société historique du Saguenay, Cahiers de Saguenayensia, Histoire des Municipalités no. 6 Imprimerie Gagné, Louiseville, QC

Bouchard M, Pothier D (2011) Long-term influence of fire and harvesting on boreal forest age structure and forest composition in eastern Québec. For Ecol Manag 261:811-820

Bouchard M, Pothier D, Gauthier S (2008) Fire return intervals and tree species succession in the North Shore region of eastern Quebec. Can J For Res 38:1621-1633

Boucher Y, Grondin P (2012) Impact of logging and natural stand-replacing disturbances on high-elevation boreal landscape dynamics (1950-2005) in eastern Canada. For Ecol Manag 263:229-239

Boucher Y, Arseneault D, Sirois L, Blais L (2009a) Logging pattern and landscape changes over the last century at the boreal and deciduous forest transition in Eastern Canada. Landscape Ecol 24:171-184

Boucher Y, Arseneault D, Sirois L (2009b) Logging history (1820-2000) of a heavily exploited southern boreal forest landscape: insights from sunken logs and forestry maps. For Ecol Manag 258:1359-1368

Carleton TJ, MacLellan P (1994) Woody vegetation responses to fire versus clear-cutting logging: a comparative survey in the central Canadian boreal forest. Ecoscience 1:141-152

Clark WAV, Hosking PL (1986) Statistical methods for geographers. Wiley, New York

Cogbill CV (1985) Dynamics of the boreal forest of the Laurentian highlands. Can J For Res 15:252-261

Couillard P-L, Payette S, Grondin P (2013) Long-term impact of fire on high-altitude balsam fir (Abies balsamea) forests in south-central Quebec deduced from soil charcoal. Can J For Res 43:188-199 
Cyr D, Gauthier S, Bergeron Y, Carcaillet C (2009) Forest management is driving the eastern North American boreal forest outside its natural range of variability. Front Ecol Environ 7:519-524

Cyr D, Gauthier S, Bergeron Y (2012) The influence of landscape-level heterogeneity in fire frequency on canopy composition in the boreal forest of eastern Canada. J Veg Sci 23:140-150

Delisle-Boulianne S, Boucher Y, Bélanger L, Brière M-H (2011) Les premiers inventaires forestiers dans la réserve faunique des Laurentides: de précieuses sources d'information pour établir le portrait des forêts naturelles. Nat Can 135:34-44

Doucet R (1988) La régénération préétablie dans les peuplements forestiers naturels du Québec. For Chron 64:116-120

Dupuis S, Arseneault D, Sirois L (2011) Change from pre-settlement to present-day forest composition reconstructed from early land survey records in eastern Québec, Canada. J Veg Sci 22:564-575

Ellis EC (2011) Anthropogenic transformation of the terrestrial biosphere. Phil Trans R Soc A 369:1010-1035

ESRI (2008) ArcGis 9.1. User's manual. Environmental Systems Research Institute, Redlands

Brothers Price, Company Ltd (1940) Forest working plan, South Kenogami Limits. The report. North woodlands division, Chicoutimi, QC

Flannigan MD, Logan KA, Amiro BD, Skinner WR, Stocks BJ (2005) Future area burned in Canada. Clim Change 72:1-16

Flatley WT, Lafon CW, Grissino-Mayer HD (2011) Climatic and topographic controls on patterns of fire in the southern and central Appalachians Mountains, USA. Landscape Ecol 26:195-209

Foley JA, DeFries R, Asner GP, Barford C, Bonan G, Carpenter SR, Chapin FS, Coe MT, Daily GC, Gibbs HK, Helkowski JH, Holloway T, Howard EA, Kucharik CJ, Monfreda C, Patz JA, Prentice IC, Ramankutty N, Snyder PK (2005) Global consequences of land use. Science 309:570-574

Foster DR, Orwlg DA, McLachlan JS (1996) Ecological and conservation insights from reconstructive studies of temperate old-growth forests. Trends Ecol Evol 11:419-424

Foster DR, Motzkin G, Slater B (1998) Land-use history as longterm broad-scale disturbance: regional forest dynamics in central New-England. Ecosystems 1:96-119

Frelich LE (1995) Old forest in the Lake States today and before European settlement. Nat Area J 15:157-167

Friedman SK, Reich PB (2005) Regional legacies of logging: departure from presettlement forest conditions in northern Minnesota. Ecol Appl 15:726-744

Gerhardt F, Foster DR (2002) Physiographical and historical effects on forest vegetation in central New England, USA. J Biogeogr 29:1421-1437

Gibson L, Lee TM, Koh LP, Brook BW, Gardner TA, Barlow J, Peres CA, Bradshaw CJA, Laurance WF, Lovejoy TE, Sodhi NS (2011) Primary forests are irreplaceable for sustaining tropical biodiversity. Nature 478:378-381

Girard C, Perron N (1989) Histoire du Saguenay-Lac-SaintJean. Institut québécois de la recherche sur la culture, Québec

Hatcher RJ (1960) Croissance du sapin baumier après une coupe rase dans le Québec. Ministère du Nord canadien et des
Ressources nationales. Division des recherches sylvicoles. Mémoire technique No. 87, Ottawa

Hellberg E, Josefsson T, Östlund L (2009) The transformation of a Norway spruce dominated landscape since pre-industrial times in northern Sweden: the influence of modern forest management on forest structure. Silva Fenn 43:783-797

Higgins SI, Richardson DM (1999) Predicting plant migration rates in a changing world: the role of long-distance dispersal. Am Nat 153:464-475

Hosmer DW, Lemeshow S, Sturdivant RX (2013) Applied logistic regression. Wiley, Hoboken

Isaaks EH, Srivastava RM (1989) An introduction to applied geostatistics. Oxford University Press, New York

Johnson EA, Gutsell SL (1994) Fire frequency models, methods and interpretations. Adv Ecol Res 25:239-283

Johnson EA, Miyanishi K (2012) The boreal forest as a cultural landscape. Ann NY Acad Sci 1249:151-165

Judd RW (1989) Aroostook: a century of logging in northern Maine. University of Maine Press, Orono

Kneeshaw D, Gauthier S (2003) Old growth in the boreal forest: a dynamic perspective at the stand and landscape level. Environ Rev 11:S99-S114

Landhäusser SM, Deshaies D, Lieffers VJ (2010) Disturbance facilitates rapid range expansion of aspen into higher elevations of the Rocky Mountains under a warming climate. J Biogeogr 37:68-76

Landres PB, Morgan P, Swanson FJ (1999) Overview of the use of natural variability concepts in managing ecological systems. Ecol Appl 9:1179-1188

Laquerre S, Leduc A, Harvey BD (2009) Augmentation du couvert en peuplier faux-tremble dans les pessières du nord-ouest du Québec après coupe totale. Écoscience 16:483-491

Lefort P, Gauthier S, Bergeron Y (2003) The influence of fire weather and land use on the fire activity of the Lake Abitibi area, Eastern Canada. Forest Sci 49:509-521

Lindbladh M, Bradshaw R (1998) The origin of present forest composition and pattern in southern Sweden. J Biogeogr 25:463-477

Martin PH, Sherman RE, Fahey TJ (2007) Tropical montane forest ecotones: climate gradients, natural disturbance, and vegetation zonation in the Cordillera Central, Dominican Republic. J Biogeogr 34:1792-1806

Nilsson C, Lepori F, Malmqvist B, Törnlund E, Hjerdt N, Helfield JM, Palm D, Östergren J, Jansson R, Brännäs E, Lundqvist $H$ (2005) Forecasting environmental responses to restoration of rivers used as log floatways: an interdisciplinary challenge. Ecosystems 8:779-800

Noble IR, Dirzo R (1997) Forests as human-dominated ecosystems. Science 277:522-525

Östlund L, Zackrisson O, Axelsson AL (1997) The history and transformation of a Scandinavian boreal forest landscape since the nineteenth century. Can J For Res 27:1198-1206

Overpeck JT, Rind D, Goldberg R (1990) Climate-induced changes in forest disturbance and vegetation. Nature 343:51-53

Parisien M-A, Miller C, Ager AA, Finney MA (2010) Use of artificial landscape to isolate controls on burn probability. Landscape Ecol 25:79-93

Pechony O, Shindell DT (2010) Driving forces of global wildfires over the past millennium and the forthcoming century. Proc Natl Acad Sci USA 107:19167-19170 
Proulx M-U (2007) Le Saguenay-Lac-Saint-Jean face à son avenir, Québec. Presses de l'Université du Québec, Québec

QMNR (2000) Carte topographique numérique du Québec 1/20 000. Photocartothèque québécoise, Québec

QMNR (2008) Norme de stratification écoforestière-Quatrième inventaire forestier. Direction des inventaires forestiers, Québec

Reich PB, Bakken P, Carlson D, Frelich L, Friedman F, Grigal D (2001) Influence of logging and fire on biodiversity and productivity in southern boreal forests. Ecology 82:2731-2748

Reiners WA, Lang GE (1979) Vegetational patterns and processes in the balsam zone, White Mountains, New Hampshire. Ecology 60:403-417

Rhemtulla JM, Mladenoff DJ, Clayton MK (2007) Regional land-cover conversion in the U.S. upper Midwest: magnitude of change and limited recovery (1850-1935-1993). Landscape Ecol 22:57-75

Robertson GP, Collins SL, Foster DR, Brokaw N, Ducklow HW, Gragson TL, Gries C, Hamilton SK, McGuire AD, Moore JC, Stanley EH, Waide RB, Williams MW (2012) Longterm ecological research in a human-dominated world. BioScience 62:342-353

Robitaille A, Saucier JP (1998) Paysages régionaux du Québec méridional. Direction de la gestion des stocks forestiers et Direction des relations publiques, Ministère des Ressources Naturelles du Québec. Les publications du Québec, QC

Rowe JS (1972) Forest regions of Canada. Publ. No. 1300. Canadian Forestry Service, Ottawa

Rowe JS, Scotter GW (1973) Fire in the boreal forest. Quat Res 3:444-464

Russel EWB (1983) Indian-set fires in the forests of the northeastern United States. Ecology 64:78-88
Sakai A, Weiser CJ (1973) Freezing resistance of trees in North America with reference to tree regions. Ecology 54:118-126

SAS Institute (2003) SAS version 9.1. SAS Institute, Cary

Törnlund E, Östlund L (2002) Floating timber in Northern Sweden: the construction of floatways and transformation of rivers. Environ Hist 8:85-106

Turner MG (2010) Disturbance and landscape dynamics in a changing world. Ecology 91:2833-2849

Vallières M, Desloges Y, Harvey F, Héroux A, Auger R, Lamontagne S-L (2008) Histoire de Québec et de sa région. Les Presses de l'Université Laval, Québec

Viereck LA, Johnston WF (1990) Picea mariana Mill BSP black spruce. In: Silvics of North America, vol 1, Conifers. USDA Forest Service, Washington DC, pp 227-237

Weir JMH, Johnson EA (1998) Effects of escaped settlement fires and logging on forest composition in the mixedwood boreal forest. Can J For Res 28:459-467

Whitney GG (1994) From coastal wilderness to fruited plain. In: A history of environmental change in temperate North America from 1500 to the present. Cambridge University press, Cambridge

Williams MA, Baker WL (2012) Spatially extensive reconstructions show variable-severity fire and heterogeneous structure in historical western United States dry forests. Global Ecol Biogeogr 21:1042-1052

Zasada J, Sharik TL, Nygren M (1992) The reproductive process in boreal forest trees. In: Shugart HH, Leemans Ret Bonan GB (eds) A system analysis of the global boreal forest. Cambridge University Press, Cambridge, pp 85-125 